\title{
An Investigation into Onshore Captive INSURANCE COMPANIES
}

\author{
M E le Roux and F J Mostert \\ Department of Business Management, University of Stellenbosch
}

\begin{abstract}
Insurance provided by captive insurers is one of various forms of risk financing. The nature and main types of captive insurance companies are discussed. This is followed by the results of an empirical study that focused on South African onshore captive insurance companies. The objectives in establishing and operating a captive insurer, the factors which determine the decision of the parent company to establish and operate a captive insurer and the future and usefulness of insurance provided by captive insurers are some of the aspects that are addressed.
\end{abstract}

JEL G22

\section{1}

\section{Introduction}

The concept of insurance provided by a captive insurer signifies the approach that is followed when an insurance company only insures the risks of its parent company or companies (Bawcutt, 1997: 1; Diacon \& Carter, 1992: 82). This implies that a captive insurer has a restricted (or captive) client base, which is limited to its owner or group of owners (Molewa, 1998: 3). The term captive was actually coined by Fred Reiss (Schroeder, 1999: 6) who began forming insurance companies for his clients under normal commercial insurance laws. When he was in Bermuda in 1962, he persuaded the authorities to allow the formation, by private act, of insurance companies that would protect the risks of a parent company only.

A captive insurance company thus provides an alternative to purchasing an insurance policy from an outside insurer (Yanchisin, 2001: 738). It should be borne in mind that, since the captive insurance company acts as insurer for its parent company or companies, the amount of premiums paid to the captive insurance company should be adequate to keep the captive insurer solvent. A study by Adams and Hillier (2000: 1804) shows that there is no firm evidence to suggest that insurance provided by captive insurers changes the risk structure of a parent company. The benefits are that a captive insurance company provides an alternative to the traditional risk financing products offered by insurance markets.

\section{2}

\section{The nature and types of captive insurance companies}

Myers (1996: 2) suggests that what a captive insurance company offers the insured is greater control of their risk management programmes and the opportunity to expand their horizons. The formalised nature of a captive insurance company facilitates better understanding, on the part of management, of global and integrated loss control within an enterprise. The cost of operating a captive insurance company is influenced by a number of fees that are payable. This method of risk financing also requires an initial capital investment by the parent company or companies, but this is generally lower than in the case of normal commercial insurers (Nilsen, 2002: 19). It should always be borne 
in mind that insurance provided by a captive insurer is speculative and long term in nature (Gjertsen, 1999: 15).

Captive insurance companies can be classified into group captive insurers or single-parent captive insurers. The group captive insurer is an insurance company formed to provide insurance to its group of owners (Petroni, 1998: 289). The owners usually consist of enterprises from related business fields. The second type of captive insurance company, a single-parent captive insurer, is an insurance company formed to provide coverage for the parent company only.

Throughout the world, the concept of captive insurance companies as they are known today has evolved rapidly. The pure captive insurer was formed into more complex and innovative structures and a variety of types of the original. Currently, the best-known types of captive insurance companies worldwide are onshore, offshore and cell captive insurance companies.

In the case of onshore captive insurance companies, insurance premiums paid by the parent company to the subsidiary in the same country may usually be deducted by the parent company for tax purposes, as the subsidiary will be taxed by the local authorities on the profits made during a financial year (Dowing, 1994: 40). As dividends paid to the parent company by the subsidiary are based on profit after taxation, the dividends will usually not be taxable in the hands of the parent company. Local authorities are usually comfortable with this type of captive insurance company. This research paper explicitly focuses on onshore captive insurers registered in South Africa.

An offshore captive insurance company is established by a local parent company as a subsidiary in another country, often in a tax haven. The profits made by the subsidiary can be taxed by the local authorities if the subsidiary is classified as a controlled foreign company under particular stipulations (Income Tax Act, section 9D). If the parent company wants to deduct the insurance premiums paid to the offshore captive insurance company for tax purposes, the parent company usually has to convince the local authorities that it forms part of a comprehensive risk management strategy.
According to Bawcutt (1997: 15), the application of exchange-control regulations by the South African Reserve Bank does not appear to inhibit the establishment of captive insurers.

A cell captive insurance company consists of various 'cells' which may be independent when insolvency occurs (Payne, 2000: 100). Each parent company can obtain a particular 'cell' and can channel its insurance needs through it. The cell captive insurance company, however, is registered as one insurer and the administration is undertaken by a centralised organisation. It may thus be less expensive for a parent company to run a particular 'cell' of a cell captive insurance company rather than its own captive insurance company.

\section{3}

\section{Objective of the research}

The objective of the research undertaken for this paper envisaged the improvement of financial decision-making by enterprises that choose an onshore captive insurer as the appropriate way to manage risks. To achieve this objective, the results of an empirical study were considered against the background of relevant literature. The conclusions that were reached should be valuable to business enterprises in particular, but also to non-profit organisations.

\section{4}

\section{Scope of the empirical study}

The empirical study covered a number of aspects dealing with the decision-making process of a parent company planning to establish and operate an onshore captive insurance company. Attention was given, inter alia, to the specific objectives that could be considered by a parent company. An attempt was made to classify the various objectives (sometimes presented as 'reasons' in the literature) for establishing and operating a captive insurer in a number of categories (Bawcutt, 1997: 17-9, 25-8, 42; Eveleigh, 2000: 2; Melamet, 1988: 268; Melamet, 1990: 67-8; Shpritz \& Calder, 1998: 2; Sudowsky \& Andre, 
1997: 1; Winston, 1999: 28). It must, however, be stated that the four categories mentioned in this research are not necessarily mutually exclusive and that classification from other viewpoints may be possible. The four categories that were used were the financial, control, flexibility and commercial objectives. The financial objectives focus mainly on the impact on profits after taxation and the cash flow of the parent company, while the control objectives encompass control over the entire risk management programme of the parent company. The flexibility objectives include flexibility in handling the changing risk financing environment of the parent company, while the commercial objectives take the protection of the assets, liabilities and the shareholders' value of the parent company into account. The significance of the four categories can be interpreted in different ways in relation to the decision to establish or to operate a captive insurance company.

The relevant literature clearly indicates that a parent company also needs to consider a number of decisional factors before implementing a risk management programme in which insurance provided by a captive insurer becomes the essential core of the parent company's alternative risk strategy. These factors include:

- Loss/premium ratio of the parent company (Petroni, 1998: 288)

- Financial commitment of the parent company (Petroni, 1998: 288)

- Spread of risk of the parent company (Petroni, 1998: 288)

- Loss control of the parent company (Anonymous, 1993: 10; Bawcutt, 1997: 43)

- Management commitment of the parent company (Bawcutt, 1997: 43-44; Zolkos, 2001: 17)

- Retention capacity of the parent company (Zolkos, 1996: 40)

- Regulation by government (Shayne, 1999: 29) and

- Managerial competence of the parent company (Bawcutt, 1997: 46; Shpritz \& Calder, 1998: 2).
The factors that determine a parent company's decision to establish and to operate a captive insurance company were investigated, and the three most important decisional factors were determined for both the establishment and the operation of a captive insurer. The strategic difference between establishing and operating a captive insurance company was clearly highlighted in the study.

\section{5}

\section{Methodology of the empirical study}

The survey was conducted by means of questionnaires sent to relevant officials at all the onshore captive insurance companies registered in South Africa. The total population for the year 2002 was obtained from the Financial Services Board (Van der Lith, e-mail, 20 November 2002). This came to a total of 14 companies.

The covering letters accompanying the questionnaires were addressed to the managing directors of the captive insurers. The decision to send the letters directly to the managing directors was based on the perception that their seniority and position within the company would influence and improve the response rate. It was also believed that the managing directors would ensure that the request for co-operation received attention at the highest level possible.

The questionnaires were sent to the 14 onshore captive insurance companies. Only eight of the 14 companies returned their questionnaires and it was therefore necessary to do follow-up by means of telephone calls to the non-responding companies. After this follow-up, 13 of the 14 onshore captive insurers responded. The one non-responsive onshore captive insurer confirmed by means of a telephone conversation that the firm no longer performed insurance activities, and therefore was no longer a member of the population of onshore captive insurance companies. Hence the actual response rate for onshore captive insurers was 100 per cent.

The reliability of the information obtained from the respondents fully depended on the honesty and the integrity of the respondents. 
The empirical findings of this study were therefore based on the opinions, knowledge and experience of the 13 respondents who completed the questionnaires. Due care was taken to ensure that the information obtained through this study could be regarded as reliable, and nothing that reflected negatively on the reliability of this information came to the knowledge of the researcher.

Eleven of the 13 respondents had already achieved management status, while five of them were senior members of the top structure of their respective enterprises. The seniority of the respondents not only made a vast field of experience available to the study, but it also meant that they were able to respond confidently about risk management practices at their companies. The seniority of the respondents was therefore seen as contributing to the reliability of the information obtained from the questionnaires.

The number of years of experience of the respondents provided further support to the perceived reliability of the obtained information. Seven of the 13 onshore captive respondents had five or more years of insurance experience at captive insurers, which represents 53.8 per cent of the population of onshore captive insurers. The most insurance experience indicated by a respondent was 14 years and the least two years.

\section{6}

\section{Results of the empirical survey}

The results of the study focused on the following aspects:

- The age of the onshore captive insurers and the number of parent companies involved in the ownership

- The objectives for establishing and operating an onshore captive insurance company

- Factors which determine the decision of a parent company to establish and operate an onshore captive insurance company and

- The future and usefulness of insurance provided by captive insurers.

\subsection{Age of the onshore captive insurers and the number of parent companies involved}

The empirical study revealed that the ages of the 13 captive insurers varied from three to 11 years, with six of the companies being older than five years. It was interesting to note that 12 of the captive insurers had only one parent company, while the other captive insurer was owned by two parent companies. These data cohere with the general theory that the establishment of an onshore captive insurer comes about when a single parent company identifies the need to have its own captive insurer.

\subsection{Objectives in establishing and operating an onshore captive insurance company}

This section emphasised the four main categories of objectives, namely the financial, control, flexibility and commercial objectives that play a role in establishing and operating an onshore captive insurer. The aim was to determine the order of significance as rated by the respondents with regard to each of the four main categories, as shown in Table 1 . The answers were ranked from seen as the most important to seen as the least important according to the number of respondents that marked specific categories of answers as 'extremely important', 'highly important', etc. In order to represent the ranking statistically, the highest weight was given to 'extremely important' and the lowest weight to 'not important'. Weighting is an accepted statistical manipulation of data when a continuum is used, in order to take into account the relative importance of answer categories (Albright et al., 2000: 224). It was explicitly stated on the questionnaire that the answers formed a continuum. The weighted scores for each category of answer were calculated, to more objectively infer the order of importance of the categories of answers, by multiplying the 'not important' frequencies by one, 'little important' frequencies by two, 'moderately important' frequencies by three, 'highly important' 
frequencies by four and 'extremely important' frequencies by five. The calculation of these weighted scores is presented in the following table.

Table 1

Sum of weighted scores of objectives in establishing and operating an onshore captive insurance company

\begin{tabular}{|l|c|c|c|c|c|c|}
\hline & $\begin{array}{c}\text { Score 'not } \\
\text { important' } \\
\times \mathbf{1}\end{array}$ & $\begin{array}{c}\text { Score 'little } \\
\text { important' } \\
\times \mathbf{2}\end{array}$ & $\begin{array}{c}\text { Score } \\
\text { 'moderately } \\
\text { important' } \\
\times \mathbf{3}\end{array}$ & $\begin{array}{c}\text { Score } \\
\text { 'highly } \\
\text { important' } \\
\times \mathbf{4}\end{array}$ & $\begin{array}{c}\text { Score } \\
\text { 'extremely } \\
\text { important' } \\
\times \mathbf{5}\end{array}$ & $\begin{array}{c}\text { Sum of } \\
\text { weighted } \\
\text { scores }\end{array}$ \\
\hline $\begin{array}{l}\text { Obtaining } \\
\text { financial } \\
\text { benefits }\end{array}$ & 0 & 0 & 12 & 20 & 20 & $\mathbf{5 2}$ \\
\hline $\begin{array}{l}\text { Obtaining } \\
\text { control }\end{array}$ & 0 & 0 & 3 & 36 & 15 & $\mathbf{5 4}$ \\
\hline $\begin{array}{l}\text { Obtaining } \\
\text { flexibility }\end{array}$ & 1 & 4 & 6 & 20 & 15 & $\mathbf{4 6}$ \\
\hline $\begin{array}{l}\text { Obtaining } \\
\text { commercial } \\
\text { objectives }\end{array}$ & 1 & 6 & 3 & 12 & 25 & $\mathbf{4 7}$ \\
\hline $\begin{array}{l}\text { Focus on } \\
\text { risk control }\end{array}$ & 0 & 0 & 0 & 4 & & \\
\hline
\end{tabular}

As can be seen from the sum of weighted scores, obtaining control is viewed as the most important objective in establishing and operating a captive insurance company. The second most important objective is obtaining financial benefits, the third most important objective encompasses commercial benefits and the fourth most important objective focuses on flexibility. One of the respondents from the onshore captive insurance companies mentioned 'focus on risk control' as a highly important additional objective to the four objectives provided in the questionnaire.

Following this, the significance of the objectives for establishing and the objectives for operating an onshore captive insurer was researched for the subsections of each of the four main categories of objectives (namely the control, financial, commercial and flexibility objectives).

\section{Table 2}

Most important control objective for an onshore captive insurance company

\begin{tabular}{|l|c|c|c|c|}
\hline \multirow{2}{*}{} & \multicolumn{2}{|c|}{ For establishing } & \multicolumn{2}{c|}{ For operating } \\
\cline { 2 - 5 } & Frequency & \% & Frequency & \% \\
\hline Control of unrelated business lines & 10 & 76.9 & 6 & 46.2 \\
\hline Control over investments & 3 & 23.1 & 6 & 46.2 \\
\hline Control over claim settlement & 0 & 0.0 & 1 & 7.6 \\
\hline Total & $\mathbf{1 3}$ & $\mathbf{1 0 0 . 0}$ & $\mathbf{1 3}$ & $\mathbf{1 0 0 . 0}$ \\
\hline
\end{tabular}


Control over underwriting lines of business that are unrelated to the risks of the parent company was seen as the most important control objective for establishing an onshore captive insurance company by more than 76 per cent of the respondents. This objective refers to the different lines of business of the various subsidiaries of the parent company. Control over the investments of the captive insurer was supported by 23.1 per cent of the respondents and none found that control over claim settlement was an important consideration in establishing an onshore captive insurer.

Responses regarding the most important control objective concerning operating an onshore captive insurance company were equally divided between control over the underwriting of the subsidiaries' lines of business that are unrelated to the risks of the parent company and control over the investments of the captive insurer, with each supported by 46.2 per cent of the respondents. Only one of the respondents felt that control over claim settlement was an important consideration with regard to operating an onshore captive insurer.

Comparison of the information in Table 2 shows that most respondents felt that control over the underwriting of the subsidiaries' lines of business that are unrelated to the risks of the parent company were very important with regard to establishing as well as operating an onshore captive insurer. With regard to operating an onshore captive insurance company, control of the investments of the captive insurer was supported by an equal number of respondents.

Table 3

Most important financial objective for establishing and for operating an onshore captive insurance company

\begin{tabular}{|l|c|c|c|c|}
\hline \multirow{2}{*}{} & \multicolumn{2}{|c|}{ For establishing } & \multicolumn{2}{c|}{ For operating } \\
\cline { 2 - 5 } & Frequency & $\%$ & Frequency & 15.4 \\
\hline Providing lower insurance costs & 7 & 53.8 & 2 & 15.4 \\
\hline Cashflow improvement & 2 & 15.4 & 2 & 46.2 \\
\hline $\begin{array}{l}\text { Cost savings through the } \\
\text { reinsurance market }\end{array}$ & 0 & 0.0 & 6 & 7.6 \\
\hline Tax minimisation and deferral & 2 & 15.4 & 1 & 15.4 \\
\hline Protection from price fluctuations & 2 & 15.4 & 2 & $\mathbf{1 0 0 . 0}$ \\
\hline Total & $\mathbf{1 3}$ & $\mathbf{1 0 0 . 0}$ & $\mathbf{1 3}$ & \\
\hline
\end{tabular}

According to Table 3, the most important financial objective in establishing an onshore captive insurance company was to provide lower insurance costs to the parent company, as indicated by more than 53 per cent of the respondents. Cashflow improvement, tax minimisation and deferral and protection from price fluctuations were each seen as the most important objective by two respondents, while cost savings through the reinsurance market was not regarded as important by any respondent.

According to 46.2 per cent of the respondents, the most important financial objective for operating an onshore captive insurance company, was the provision of cost savings through the reinsurance market to the parent company. Providing lower insurance costs, cashflow improvement and protection from price fluctuations were regarded as the most important objectives by two respondents each. Tax minimisation and deferral was seen as the most important objective in operating a captive insurer by only one respondent.

Comparing the information in Table 3 makes it clear that there is a significant difference between the decision to establish and the decision to operate an onshore captive insurance company on the basis of financial 
objectives. Most respondents indicated that the most important objective in establishing an onshore captive insurer lies in the fact that it resulted in lower insurance costs, while most respondents indicated that, in the case of operating the onshore captive insurers, cost savings were achieved through the reinsurance market.

Table 4

Most important commercial objective for establishing and for operating an onshore captive insurance company

\begin{tabular}{|l|c|c|c|c|}
\hline \multirow{2}{*}{} & \multicolumn{2}{|c|}{ For establishing } & \multicolumn{2}{c|}{ For operating } \\
\cline { 2 - 5 } & Frequency & $\%$ & Frequency & 15.4 \\
\hline Providing lower insurance costs & 7 & 53.8 & 2 & 46.2 \\
\hline $\begin{array}{l}\text { Risk-retention levels set according to } \\
\text { needs of parent company }\end{array}$ & 10 & 76.9 & 6 & 23.0 \\
\hline $\begin{array}{l}\text { Maximise shareholders' value of the } \\
\text { parent company }\end{array}$ & 2 & 15.4 & 3 & 30.8 \\
\hline Strategic risk-management & 1 & 7.7 & 4 & $\mathbf{1 0 0 . 0}$ \\
\hline Total & $\mathbf{1 3}$ & $\mathbf{1 0 0 . 0}$ & $\mathbf{1 3}$ & \\
\hline
\end{tabular}

According to Table 4, the most important commercial objective in establishing an onshore captive insurance company, as perceived by more than 76 per cent of the respondents, was that the risk retention levels were set according to the needs of the parent company. Two respondents supported maximising share-holders' value of the parent company as the most important objective, and one of the respondents indicated that strategic risk management was an important commercial objective in establishing an onshore captive insurer.

According to Table 4, risk retention levels set according to the needs of the parent company was perceived by 46.2 per cent of the respondents as the most important commercial objective in operating an onshore captive insurance company. Strategic risk management was selected as the most important objective in operating an onshore captive insurance company by four of the respondents. Maximisation of shareholders' value of the parent company was indicated as the most important commercial objective in operating an onshore captive insurance company by three respondents.

Comparison of the information in Table 4 clearly indicates that most respondents felt that having risk retention levels set according to the needs of the parent company was the most important commercial objective, both in establishing and in operating an onshore captive insurance company.

\section{Table 5}

Most important flexibility objective for an onshore captive insurance company

\begin{tabular}{|l|c|c|c|c|}
\hline \multirow{2}{*}{} & \multicolumn{2}{|c|}{ For establishing } & \multicolumn{2}{c|}{ For operating } \\
\cline { 2 - 5 } & Frequency & $\%$ & Frequency & \\
\hline \multirow{2}{*}{$\begin{array}{l}\text { Availability of coverage not otherwise } \\
\text { available }\end{array}$} & 8 & 61.5 & 7 & 53.8 \\
\hline Access to the reinsurance market & 4 & 30.8 & 6 & 46.2 \\
\hline Regulatory flexibility of domiciles & 1 & 7.7 & 0 & 0.0 \\
\hline Total & $\mathbf{1 3}$ & $\mathbf{1 0 0 . 0}$ & $\mathbf{1 3}$ & $\mathbf{1 0 0 . 0}$ \\
\hline
\end{tabular}


From Table 5 it is clear that the availability of coverage not otherwise available was seen as the most important flexibility objective in establishing an onshore captive insurance company by more than 61 per cent of the respondents. The next most important objective, which had the support of 30.8 per cent of the respondents, was the access to the reinsurance market that a captive insurer can provide for the parent company. Only one of the respondents felt that regulatory flexibility of domiciles was important in establishing an onshore captive insurer.

Availability of coverage not otherwise available was also perceived by 53.8 per cent of the respondents as the most important flexibility objective concerning operating an onshore captive insurer. Access to the reinsurance market was supported by 46.2 per cent of the respondents as the most important objective concerned in operating an onshore captive insurance company. None of the respondents found that regulatory flexibility of domiciles plays an important role in operating an onshore captive insurer.

By comparing the information of Table 5, it becomes clear that the availability of coverage not otherwise available is regarded by most respondents as a very important flexibility objective in establishing as well as in operating an onshore captive insurance company. The flexibility objective of access to the reinsurance market was also supported, by a reasonable number of respondents, as important in establishing and operating an onshore captive insurer.

Based on Tables 1 to 5 , the following are presented as main objectives, in descending order of importance:

\section{Firstly, obtaining control objectives:}

- The most important control objective in establishing an onshore captive insurance company was identified as control over the underwriting of the subsidiaries' lines of business that are unrelated to the risks of the parent company.

- The most important control objective in operating an onshore captive insurance company was identified as control over the underwriting of the subsidiaries' lines of business that are unrelated to the risks of the parent company, together with control of the investments of the captive insurer.

Secondly, obtaining financial benefits:

- The most important financial objective in establishing an onshore captive insurance company was identified as the provision of lower insurance costs.

- The most important financial objective in operating an onshore captive insurance company was identified as the provision of cost savings through the reinsurance market.

Thirdly, obtaining commercial objectives:

- The most important commercial objective in establishing and operating an onshore captive insurance company was identified as the ability to set the risk-retention levels according to the needs of the parent company.

Fourthly, obtaining flexibility:

- The most important flexibility objective in establishing and operating an onshore captive insurance company was identified as the availability of coverage not otherwise available.

\subsection{Factors which determine the decision of a parent company to establish and operate an onshore captive insurance company}

The respondents were asked to indicate four factors that determine the decision of a parent company to establish and operate an onshore captive insurance company. The results are presented in Table 6. It can be concluded from the preceding table that the three most important factors determining the decision of a parent company to establish an onshore captive insurance company, as indicated by the largest number of respondents, are as follows:

- the financial commitment of the parent company to financially support the captive insurer when necessary 
- the spreading of the risks of the parent company; and
- the retention capacity of the parent company, which may increase or decrease the necessity of having a captive insurer.

\section{Table 6}

The four most important factors that, according to the individual respondents, determine the decision of a parent company to establish and operate an onshore captive insurance company

\begin{tabular}{|l|c|c|}
\hline & To establish & To operate \\
\hline Importance of the loss/premium ratio of the parent company & 4 & 5 \\
\hline Importance of the financial commitment of the parent company & 11 & 7 \\
\hline Importance of spreading the risks of the parent company & 9 & 6 \\
\hline Importance of the loss control of the parent company & 5 & 4 \\
\hline Importance of the management commitment of the parent company & 6 & 7 \\
\hline Importance of the retention capacity of the parent company & 8 & 5 \\
\hline Importance of regulation by government & 7 & 4 \\
\hline Importance of the managerial competence of the parent company & 1 & 0 \\
\hline Importance of tailor-made service to the parent company & 0 & 3 \\
\hline Importance of the managerial competence of the captive insurer & 0 & 1 \\
\hline Importance of the risk profile of the parent company & 0 & 1 \\
\hline Importance of flexibility & $\mathbf{5 2}$ & $\mathbf{5 2}$ \\
\hline Total $(13$ respondents $\times 4$ factors each) & & 5 \\
\hline
\end{tabular}

The information in Table 6 also leads to the conclusion that the three most important factors determining the decision of a parent company to operate an onshore captive insurance company, as indicated by the largest number of respondents, are as follows:

- the retention capacity of the parent company, which may increase or decrease the necessity of having a captive insurer

- the financial commitment of the parent company to financially support the captive insurer when necessary and

- the management commitment of the parent company.

Comparison of the two preceding conclusions indicates that the financial commitment of the parent company and the retention capacity of the parent company are significant elements that the risk manager should include in the company's decision-making process when establishing and operating an onshore captive insurer. Spreading the risks of the parent company is important in establishing an onshore captive insurer, while the management commitment of the parent company is important when operating an onshore captive insurer.

\subsection{Future and usefulness of insurance provided by captive insurers}

More than 84 per cent of respondents were of the opinion that their captive insurance company should be regarded as a long-term alternative risk transfer mechanism for the parent company. Furthermore, it is important to note that more than 92 per cent of the respondents felt that their onshore captive insurers were successfully reducing the risk exposure of the parent company, and that insurance provided by captive insurers would become more important during the following five years. Motivations from respondents who 
believed that insurance provided by captive insurers would become more important included the following:

- the changing global market conditions that force companies to adapt and the cost of risk transfer that could be decreased by having an own financial vehicle to retain high levels of self-insurance

- the high cost of alternatives presented by the traditional insurance market

- the limitations of available coverage from traditional insurers

- self-insurance as a valuable tool for accessing the reinsurance market

- earning of investment income on funds and

- provision of an additional service to clients.

\section{7}

\section{Conclusions}

This study has led to the following important conclusions with regard to the establishment and operation of onshore captive insurance companies in South Africa:

(1) When a parent company decides to utilise insurance provided by a captive insurer, the parent company usually prefers to establish and operate its own captive insurance company and such a step is regarded as a medium- to long-term commitment by the parent company.

(2) Special attention should be paid to the objectives that parent companies want to achieve when insurance provided by captive insurers is chosen as a way of risk financing. The objectives may focus on obtaining control, financial benefits, commercial benefits and flexibility. Different objectives may be applicable for the establishment and for the operation of an onshore captive insurance company. Without proper clarification and definition of the objectives for establishing and operating an onshore captive insurer, a parent company may come to the prejudiced conclusion that insurance provided by a captive insurer is not worthwhile.
(3) The financial commitment of the parent company and its retention capacity are crucial factors that management should consider during the company's decisionmaking process towards establishing and operating an onshore captive insurer. Spreading the risks of the parent company is also important in establishing an onshore captive insurer, while the management commitment of the parent company is vital for operating an onshore captive insurer.

(4) Insurance by captive insurers provides parent companies with a long-term alternative risk transfer mechanism. Furthermore, there is little doubt that captive insurance companies succeed in reducing the risk exposure of a parent company (which is contrary to the conclusion of Adams and Hillier (2000: 1804). This way of risk financing should become more important in future as it provides an alternative to the traditional insurance market.

\section{References}

1 ADAMS, M. \& HILLIER, D. (2000) "The effect of captive insurer formation on stock returns: An empirical test from the UK", Journal of Banking \& Finance, 24(11): 1787-808.

2 ALBRIGHT, S.C.; WINSTON, W.L. \& ZAPPE, C.J. (2000) Managerial Statistics, Duxbury: United States of America.

3 ANONYMOUS (1993) "Loss management for captives", ReActions (Loss Management Services Supplement) October: 10-13.

4 BAWCUTT, P. (1997) Captive Insurance Companies: Establishment, Operation and Management ( $4^{\text {th }}$ ed.) Witherby and Co: London.

5 DIACON, S.R. \& CARTER, R.L. (1992) Success in Insurance ( $3^{\text {rd }}$ ed.) John Murray: Great Britain.

6 DOWING, T. (1994) "Onshore drift", ReActions, 14(4): 40.

7 EVELEIGH, M. (2000) "Captive insurance companies - What are they?", KPMG Publication, March: 1-2.

8 GJERTSEN, L. (1999) "Agents take piece of risk via captives", National Underwriter (Property \& Casualty/Risk \& Benefits Management), 103(11): 15. 
9 INCOME TAX ACT, No. 58 of 1962, as amended.

10 MELAMET, D.A. (1988) "Report of the commission of inquiry into the winding-up of the short-term insurance business of the AA Mutual Insurance Association Limited”, RP 82/1988, Government Printer: Pretoria.

11 MELAMET, D.A. (1990) "Report of the commission of inquiry into the flow of shortterm insurance premiums out of the Republic and the operations of captive insurers", RP 53/ 1990, Government Printer: Pretoria.

12 MOLEWA, M. (1998) "The strategic role of cell captives in risk management”, Master's Thesis, Johannesburg: University of the Witwatersrand.

13 MYERS, G.K. (1996) "The alternative insurance market: A primer”, John Liner Review, Fall: 1-9.

14 NILSEN, M.J. (2002) "Captives a work of ART in hard markets", National Underwriter (Property \& Casualty/Risk \& Benefits Management), 106(9): 18.

15 PAYNE, H. (2000) "Cost-effective insurance with a competitive edge", Financial Mail, 24 November: 100.

16 PETRONI, A. (1998) "Role, scope and operations of a captive insurance company in large technology-based multinationals: A case comparison”, Technology, Law and Insurance, 3: 285-94.

17 SCHROEDER, S. (1999) "A captive web", Risk Management, 46(3): 6.

18 SHAYNE, L.K. (1999) "Captive insurance companies - Your risk management angle", The CPA Journal, 69(4): 28-31.

19 SHPRITZ, N. \& CALDER, A. (1998) "Why dream of captives in today's insurance market", Liberty Mutual Group, October: 1-4.

20 SUDOWSKY, R. \& ANDRE, J. (1997) "How highly rated captives get that way", Risk \& Equity Manager, December: 1-5.

21 VAN DER LITH, M. (2002) E-mail from Financial Services Board (20 November).

22 WINSTON, P.D. (1999) "Control helps captives retain popularity”, Business Insurance, 33(9): 28.

23 YANCHISIN, H.S. (2001) "Captive insurance update”, The Tax Adviser, 32(11): 738-9.

24 ZOLKOS, R. (1996) "Strategic look at risk may reveal new solutions", Business Insurance, 30(50): 40-1.

25 ZOLKOS, R. (2001) "Capital requirements a delicate balance for captives", Business Insurance, 35(48): 17. 